Н. Н. Климентьева, Т. С. Олзоева. Коррекция школьной тревожности у детей младшего школьного возраста средствами анималотерапии

Научная статья

УДК 37.015 .3

DOI: $10.18101 / 2307-3330-2021-1-71-76$

\title{
КОРРЕКЦИЯ ШКОЛЬНОЙ ТРЕВОЖНОСТИ У ДЕТЕЙ МЛАДШЕГО ШКОЛЬНОГО ВОЗРАСТА СРЕДСТВАМИ АНИМАЛОТЕРАПИИ
}

\author{
(C) Климентьева Наталья Николаевна \\ кандидат психологических наук, доцент, \\ Бурятский государственный университет имени Доржи Банзарова \\ Россия, 670000, г. Улан-Удэ, ул. Смолина, 24а \\ klim.natali@mail.ru

\section{(C) Олзоева Татьяна Сергеевна} \\ студент, \\ Бурятский государственный университет имени Доржи Банзарова \\ Россия, 670000, г. Улан-Удэ, ул. Смолина, 24а \\ tanchik_btr@inbox.ru
}

\begin{abstract}
Аннотация. Статья посвящена определению роли анималотерапевтических средств в коррекции школьной тревожности детей младшего школьного возраста. Авторами раскрыты понятия «школьная тревожность» и «анималотерапия». Приводятся данные диагностики школьной тревожности младших школьников. Обоснована актуальность и охарактеризована коррекционная программа по снижению тревожных состояний младших школьников, связанных со школьной жизнью, при помощи образов животных. Представлены результаты статистического анализа, которые подтверждают эффективность использования средств анималотерапии в коррекции школьной тревожности младших школьников.
\end{abstract}

Ключевые слова: школьная тревожность, анималотерапия, младший школьный возраст, животные, психологическое благополучие, коррекция

\section{Для цитирования}

Климентьева Н. Н., Олзоева Т. С. Коррекция школьной тревожности у детей младшего школьного возраста средствами анималотерапии // Вестник Бурятского государственного университета. Образование. Личность. Общество. 2021. Вып. 1. С. 71-76.

В настоящее время тревожность является одним из наиболее распространенных феноменов психического развития, которые встречаются в школьной практике. Проблема профилактики и коррекции школьной тревожности заслуживает особенного внимания, поскольку, складываясь в определенное свойство и личностное качество учащегося в младшем школьном возрасте, тревожность вполне может стать устойчивой личностной чертой далее в подростковом возрасте, а также причиной неврозов и психосоматических заболеваний уже во взрослой жизни.

Е. К. Лютова и Г. Б. Монина считают, что школьная тревожность начинает формироваться, когда ребенок сталкивается с требованиями обучения и кажущейся невозможностью им соответствовать [4]. По мнению Л. А. Хотиной, под школь- 
ной тревожностью подразумевается одна из классических проблем в условиях школы, которая оказывает неблагоприятное воздействие не только на учебу, но и на общение ребенка в школе и за ее пределами, а также на здоровье и общий уровень психологического благополучия [6]. Тревожные дети отличаются частыми проявлениями беспокойства и тревоги, а также большим количеством страхов, для них характерна повышенная чувствительность, мнительность, впечатлительность, низкая самооценка.

Среди основных причин школьной тревожности ряд авторов (А. Л. Вегнер, Б. И. Кочубей, Е. В. Новикова, О. А. Слепичева, Е. Р. Хабирова, А. К. Дусавицкий) выделяют учебные перегрузки, постоянно повторяющиеся оценочноэкзаменационные ситуации, неблагоприятные отношения с учителями и сверстниками, неадекватные требования со стороны родителей и учителей, смену учебного коллектива.

Большинство страхов младших школьников лежат в сфере образовательной деятельности: страх «быть неправым», страх совершить ошибку, страх получить плохую оценку, боязнь конфликта со сверстниками. В связи с вышесказанным А. Я. Варламова утверждает, что школьные страхи лишают ребенка психологического комфорта, радости учения, а также способствуют развитию детских неврозов, детской школьной дезадаптации [2]. В связи с чем особую значимость приобретает поиск условий коррекции тревожности детей младшего школьного возраста. Среди многочисленных методов и средств укрепления психологического здоровья и эмоциональной стабильности младших школьников особое место отводится анималотерапии.

Анималотерапия - это вид терапии, который использует животных и их образы (изображения, рисунки, сказочных персонажей, игрушки) для оказания психотерапевтической помощи [3].

Благодаря исследованиям Э. М. Тагиевой известно, что взаимодействие людей с животными способствует снятию стресса, нормализации работы нервной системы и психики в целом, гармонизации межличностных отношений, удовлетворению потребностей в компетентности и самореализации. Кроме того, в процессе взаимодействия ребенка с животными реализуется одна из важнейших функций - функция общения, компенсация одиночества [5]. В создании метафор посредством изображения животных Б. Д. Карвасарский видит способ разрешения психологически трудных ситуаций. Включая изображения различных видов животных в образовательные и терапевтические мероприятия, Марта Борджи (Marta Borgi) выявила, что это стимулирует детей быть внимательными и повышает уровень их мотивации [1].

Наша исследовательская работа, направленная на коррекцию школьной тревожности детей младшего школьного возраста средствами анималотерапии, осуществлялась на базе МАОУ СОШ № 51 г. Улан-Удэ. В исследовании приняли участие 43 учащихся в возрасте 6-8 лет (20 человек вошли в экспериментальную группу (ЭГ) и 23 - в контрольную (КГ)). На начальном этапе в рамках констатирующего эксперимента проведена диагностика школьной тревожности по следующим критериям: особенности эмоционального состояния (методика «Паро- 
Н. Н. Климентьева, Т. С. Олзоева. Коррекция школьной тревожности у детей младшего школьного возраста средствами анималотерапии

возик» С. В. Велиевой); уровень удовлетворенности школьной жизнью (проективная рисуночная методика «Школа зверей»); тревожные для ребенка ситуации (методика «Шкала тревожности ребенка» А. М. Прихожан); оценка уровня тревожности ребенка с позиции родителя (экспресс-анкета для родителей Г. П. Лаврентьевой, Т. М. Титаренко).

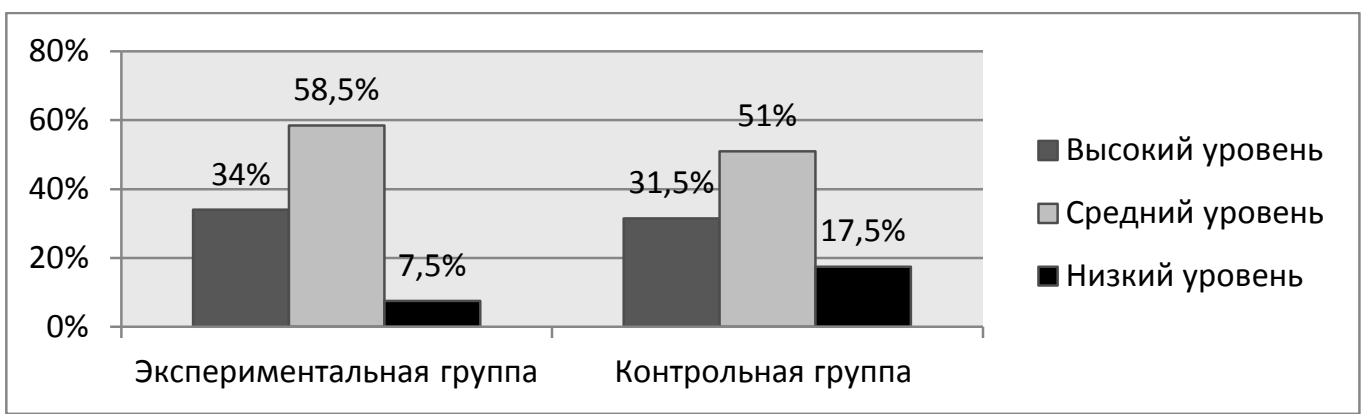

Рис. 1. Уровень школьной тревожности у младших школьников на констатирующем этапе (в \%)

В ходе констатирующего этапа было выявлено, что у 34\% учащихся ЭГ и $31,5 \%$ КГ высокий тревожности (рис. 1). Высокий уровень тревожности свидетельствует об эмоциональном неблагополучии детей, которое может существовать даже вопреки объективному благополучному положению. Для таких детей характерна высокая впечатлительность, эмоциональность, что также может свидетельствовать о реальном неблагополучии их социального положения в семье, детском саду или среди сверстников. Более половины детей ЭГ $(58,5 \%)$ и $51 \%$ учащихся КГ продемонстрировали средний уровень школьной тревожности. Детей со средним уровнем тревожности характеризует обладание необходимым уровнем готовности к реагированию на разнообразные стимулы. 7,5\% детей ЭГ и $17,5 \%$ КГ не испытывают тревожных ситуаций, связанных со школой. Для них характерна нечувствительность к неблагополучию, которая носит, как правило, компенсаторный, защитный характер и препятствует полноценному формированию личности. Ребенок достигает такого эмоционального благополучия путем неадекватного отношения к действительности, которое отрицательно сказывается на продуктивности деятельности.

Полученные данные указывают на необходимость проведения специальной работы, направленной на коррекцию школьной тревожности у детей младшего школьного возраста.

Разработанная нами коррекционная программа по снижению школьной тревожности у детей младшего школьного возраста средствами анималотерапии под названием «В мире животных» включала в себя игры и игровые упражнения; и маготерапевтические и арт-терапевтические техники, релаксационные упражнения, просмотр мультфильмов и прослушивание сказок, моделирование проблемных учебных ситуаций. Данная программа состоит из 8 занятий, которые реали- 
зовывались в течение 4 недель. Занятия проводились 2 раза в неделю длительностью по 40 минут.

Реализация формирующего эксперимента включала три основных этапа:

1. Подготовительный этап - 1 занятие: «Кто сказал "Мяу"?»;

2. Основной этап - 6 занятий: «Мой друг собака», «Четыре лапы и пушистый хвост», «Наши лесные друзья», «В царстве птиц», «Несуществующее животное», «В мире животных».

3. Заключительный этап - 1 занятие: «Путешествие по зоопарку».

На подготовительном этапе дети знакомились друг с другом, разрабатывали правила поведения на занятиях. На этом этапе были подобраны несложные и интересные игры и упражнения, чтобы новая обстановка для детей не была пугающей и утомительной. Целью первого занятия является знакомство детей друг с другом, максимальное сотрудничество в совместной деятельности, а также снятие эмоционального и мышечного напряжения.

На основном этапе добавлялись игры и упражнения, требующие от детей умения формулировать собственное мнение и отстаивать его в группе сверстников, а также принимать отличную от собственной точку зрения. Кроме того, детям необходимо было попытаться примерить на себя новую роль, которая может отличаться от уже имеющихся особенностей поведения. Вместе с тем нами применялись упражнения на развитие творческого воображения и волевых качеств (усидчивость, внимательность, умение следовать инструкции) в процессе рисования и складывания оригами. Бумажная фигурка животных, созданная своими руками, имела для детей особую ценность и становилась неотъемлемым атрибутом последующих занятий. Центральной частью основного этапа формирующего эксперимента являлись упражнения, которые были направлены на моделирование детьми учебных ситуаций, зачастую являющихся для них тревожными. Детям необходимо было проиграть различные проблемные ситуации школьной жизни и найти способы их разрешения, вживаясь в роли животных, используя их повадки.

На заключительном этапе подводился итог предыдущих занятий, проводились игры и упражнения на снятие напряжения, развитие эмпатии и умения договариваться, формирование положительного отношения к проведенным занятиям.

Основным условием проведения всех упражнений является оказание помощи психолога детям в познании себя и других, а не подавление детской инициативы. Во время реализации коррекционных занятий дети смогли научиться формулировать собственное мнение и участвовать в групповых обсуждениях, познакомились с различными средствами самоуспокоения и релаксации, в частности при обучении технике оригами научились вживаться в несвойственные для себя роли и действовать в соответствии с ними. Кроме того, используемые нами игры и упражнения позволили детям усвоить правила школьной жизни в игровом процессе.

В ходе контрольного этапа было выявлено, что в ЭГ на 14\% уменьшилось количество детей с высоким уровнем школьной тревожности (до $20 \%$ ); более чем в 
Н. Н. Климентьева, Т. С. Олзоева. Коррекция школьной тревожности у детей младшего школьного возраста средствами анималотерапии

2 раза увеличилось количество детей с низким уровнем тревожности $(16 \%)$ и на $6 \%$ детей со средним уровнем (64\%) (рис. 2).

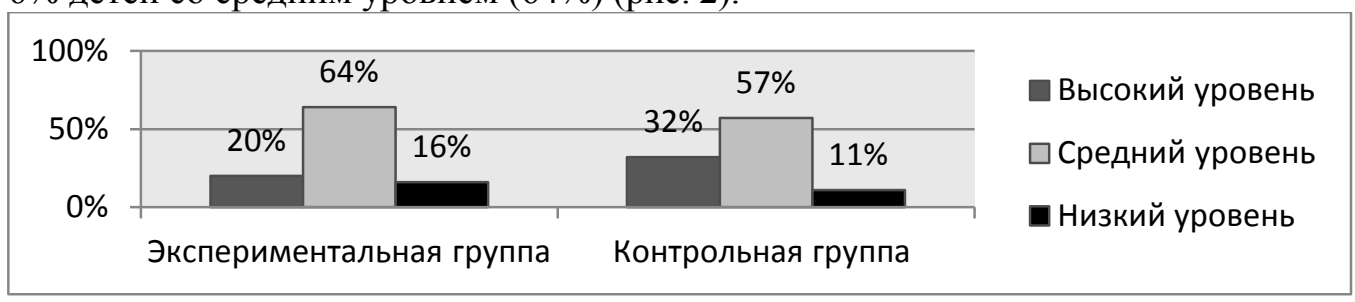

Рис. 2. Уровень школьной тревожности у младших школьников на контрольном этапе (в \%)

Статистический анализ данных, осуществленный с помощью t-критерия Стьюдента, показал значимость различий в ЭГ на констатирующем и контрольном этапах по четырем значениям (при уровне значимости $\mathrm{p}=2.86$ ): «Диагностика особенностей эмоционального состояния ребенка» $(\mathrm{t}=3)$, «Определение тревожных ситуаций для ребенка» $(\mathrm{t}=3.5)$, «Межличностная тревожность» $(\mathrm{t}=3.5)$ и «Общая тревожность» $(\mathrm{t}=3)$, «Оценка уровня тревожности ребенка с позиции родителя〉 $(\mathrm{t}=3.4)$. В контрольной группе не наблюдается значимых различий в уровне школьной тревожности на констатирующем и контрольном этапах.

Таким образом, можно сделать вывод, что средства анималотерапии (игры, сказки и мультфильмы о животных, оригами, рисунки, игрушки, изображения животных) являются эффективными в работе по снижению школьной тревожности у детей младшего школьного возраста.

Лumepamypa

1. Baby schema in human and animal faces induces cuteness perception and gaze allocation in children / M. Borgi [et al.] // Frontiers in Psychol. 2014. № 5. P. 1-12.

2. Варламова А. Я. Школьная адаптация. Волгоград: ВолГУ, 2010. 204 с.

3. Деребо С. Д., Ясвин В. А. Экологическая педагогика и психология. Ростов-наДону, 1996. С. 74-75.

4. Лютова Е. К., Монина Г. Б. Шпаргалка для взрослых: психокоррекционная работа с гиперактивными, агрессивными, тревожными и аутичными детьми. Москва, 2000. 82 с.

5. Тагиева Э. М. Анималотерапия - как метод психокоррекционной работы с детьми дошкольного и школьного возрастов // Молодой ученый. 2017. № 14.1(148.1). С. 21-24.

6. Хотина Л. А. Психолого-педагогическая коррекция школьной тревожности младших подростков // Концепт: научно-методический электронный журнал. 2015. Т. 10. С. $146-150$.

Статья поступила в редакциию 09.02.2021; одобрена после рецензирования 25.03.2021; принята к публикациии 09.04.2021. 


\section{CORRECTION OF SCHOOL-BASED ANXIETY IN PRIMARY SCHOOLCHILDREN BY MEANS OF ANIMAL-ASSISTED THERAPY}

Natalya N. Klementyeva

Cand. Sci. (Psychology), A/Prof.,

Dorzhi Banzarov Buryat State University

24a Smolina St., Ulan-Ude 670000, Russia

klim.natali@mail.ru

Tatyana S. Olzoeva

Student,

Dorzhi Banzarov Buryat State University

24a Smolina St., Ulan-Ude 670000, Russia

tanchik_btr@inbox.ru

Abstract. The article defines the role of animal-assisted therapy in the correction of schoolbased anxiety in primary schoolchildren. We reveal the concepts of «school-based anxiety» and «animal-assisted therapy», and present the results of school-based anxiety diagnosis in primary schoolchildren. The article substantiates the relevance of the correctional program aimed at reducing the school-based anxiety of primary schoolchildren by means of animal images. We present the results of statistical analysis, which confirm the effectiveness of using animal-assisted therapy in the correction of school-based anxiety in primary schoolchildren.

Keywords: school-based anxiety; animal therapy; primary school age; animals; mental well-being; correction.

\section{For citation}

Klementyeva N. N., Olzoeva T. S. Correction of School-Based Anxiety in Primary Schoolchildren by Means of Animal-Assisted Therapy. Education. Person. Society. 2021; 1: 71-76 (In Russ.).

The article was submitted 09.02.2021; approved after reviewing 25.03.2021; accepted for publication 09.04.2021. 